\title{
Improvement of interpersonal and intrapersonal intelligence through traditional games
}

\author{
Ade Ratih Prativi ${ }^{1}$; Yulia Ayriza ${ }^{2}$ \\ Graduate School of Universitas Negeri Yogyakarta, Jl. Colombo No. 1, Yogyakarta, Indonesia ${ }^{1}$ \\ Department of Psychology, Universitas Negeri Yogyakarta, Jl. Colombo No. 1, Yogyakarta, Indonesia ${ }^{2}$ \\ aderatihpratiwi@gmail.com ${ }^{1}$; yuliaayriza@yahoo.com²
}

\begin{abstract}
This study aims to: (1) improve interpersonal intelligence through traditional games for Kindergarten A students of RumahKu Tumbuh, (2) increase intrapersonal intelligence through traditional game on Kindergarten A students of RumahKu Tumbuh, and (3) describe the process of improving interpersonal and intrapersonal intelligence through these traditional games. This study is a classroom action research, referring a modified version of the Kemmis and Taggart model. Data were collected using observation and interviews. The findings show that there is an increase in interpersonal and intrapersonal intelligence through traditional game on kindergarten. Improved interpersonal intelligence of children overall in the pre-cycle obtained an average score of 22.59 (very low category), increased to 27.06 in cycle 1 (low category), and increased again to 34.65 with category in cycle 2. As for the increase in child intrapersonal intelligence overall score obtained in the pre-cycle average of 16.82 with a very low category, increasing to 21.35 with a low category in cycle 1 and increased again to 25.88 with category in cycle 2 . The process of improving interpersonal intelligence through play action includes child benefit interact in-game, effective communication when asked and answered during play, and pursuing a strategy to win in the game, while at the intrapersonal include children express their emotions in the game, and children know their feelings by doing a question and answer session with the teachers at the end of the game.
\end{abstract}

Keywords: traditional games, interpersonal intelligence, intrapersonal intelligence

\section{Introduction}

Children's development occurs through a continuously-changing pattern, starting from conception to throughout their lifetime (Santrock, 2011, p.7). The law of the Republic of Indonesia year 2003 number 20 states that every developmental stage is expected to increase quantitatively and qualitatively from one stage to the next. Development also shows a set of human development that affects each other from one stage to another. The level of maturity and external experiences also distinguishes one individual to the rest during each developmental stage. This is shown by the skill of various personal development aspects of each child.

Children in their early childhood are individuals who are currently experiencing rapid growth. The phase is commonly known as the golden age because children could expand all their development aspects during this age (Papilia \& Feldman, 2014, p.68). Because every child's development is differ- ent, it is expected that they would have their own unique trait.

Thus, particular attention needs to be put on the uniqueness of early childhood development, ensuring that every child's unique characteristic (i.e., religion, moral, physicalmotoric, cognitive, language, socio-emotion, art) are balanced and developed optimally.

A children development specialist, Lev Vygotsky (Brewer, 2007, p.9), said that development and education could not be separated since the beginning of human existence. Consequently, early-childhood education should provide proper stimulation for children's various aspects of development. One of these aspects is the cognitive development, which according to Vygotsky is a learning process derived from social context.

In early childhood education, a welldeveloped intelligence will enable children to interact with other people. Someone with high intelligence is more appreciated in our society (Sujiono, 2013, p.196). 
Concerning the term 'intelligence', Gardner (2006, p. 34) stated that there are nine different types of intelligence, namely verbal, logical, visual, kinesthetic, music, intrapersonal, interpersonal, naturalist, and existentialist. Many of these types of intelligence are widely applied by the students (deNevers, 2014, p.1).

According to Gardner, interpersonal intelligence is related to the skill to comprehend will, motivation, and intention of other people. It enables people to work effectively with others (Smith, 2008, p. 28). Independent students will adjust their goal and choice in response to the change in interpersonal and intrapersonal condition (Sungur \& Tekkaya, 2006 p.307).

However, several individuals lack interpersonal skills, causing them to have difficulties building relationships with other people. This will affect consequently affect their next stage of development. Most evidently, children will typically have problems in interacting or having social relationships with their friends.

To ensure good interpersonal skill, one type of intelligence assumed to have relation with interpersonal intelligence is intrapersonal intelligence. Gardner (2013, p.51) stated that both interpersonal and intrapersonal intelligence offers significant problem-solving capacities for the individual. Interpersonal intelligence enables someone to understand and work with other people. Meanwhile, intrapersonal intelligence works with their self. In individual's internal feeling, someone faces the combination of the interpersonal and intrapersonal combination.

Children in their early childhood who has not fully developed their intrapersonal skills may exhibit difficulties in controlling their emotions. This is strengthened by the interview results with several early-childhood education teachers on March 3, 2015, at 7 PM Indonesia Western Time. The finding shows that children in their early-childhood shows uncontrollable emotions. Children express their anger and annoyance in the class by rolling on the floor, demanding to have their friend's toy, not wanting to share their food or lend their belongings because they were treated similarly by their friends, pushing their friend, and crying when their request is not fulfilled by the teacher.

Zillman (in Saad, 2006, p.3) said that these various negative emotions shown by children could cause unexpected behaviors such as aggression. Aggression is related to the relationship between individuals and their surrounding environment. If their environment supports their existence, aggression could be controlled and vice versa. In conditions where children are still unable to show good interpersonal and intrapersonal skills, teachers should guide and hone habits that stimulate children's these types of intelligence.

On a previous study that we have conducted on RumahKu Tumbuh (RKT) Kindergarten through pre-observation by the kindergarten's teacher, we found that children still need to improve their interpersonal and intrapersonal skills. This is shown by the data obtained. The mean score of children's interpersonal intelligence was 22.59, which is considered very low. Meanwhile, the mean score of children's intrapersonal intelligence resulted in a score of 16.82 which is also very low. Thus, it can be concluded that RKT Kindergarten should optimize the students' interpersonal and intrapersonal intelligence.

In the field situation, Lwin (2008, p.198) stated that generally, someone shows low interpersonal intelligence because he or she were rarely given a chance to develop this skill when he or she was young. Thus, more attention needs to be put into the development of interpersonal and intrapersonal skills at schools. Children should be given various stimulus to expand interpersonal and intrapersonal skills, one of which is through games.

Dockett and Fleer (Sujiono, 2013, p.144) believe that playing is a medium for socializing. Playing gives children the chance to explore, discover, express their feeling, create, and learn in a fun way. Additionally, playing could help children learn about themselves (intrapersonal intelligence), as well as the people and environment around them (interpersonal).

Indonesian culture has many traditional games that could be used as mediums to op- 
timize children's development. It could help develop early childhood skills to interact with other people (interpersonal) and understand themselves (intrapersonal).

This research used Jamuran traditional game that benefits not only themselves, but also aids in improving student-teacher relation. Jamuran influences interpersonal intelligence. A group game allows the players to interact with each other excitingly without pressure, allowing their motoric, intelligence, socio-emotional, and language skills to be expanded. Furthermore, Jamuran also influences intrapersonal intelligence. Children play and show their expression freely. Therefore, children's intrapersonal and interpersonal intelligence are expected to develop optimally through Jamuran.

Jamuran has never been applied before to improve students' interpersonal and intrapersonal intelligence at RKT kindergarten. Therefore, we are motivated to observe the improvement of interpersonal and intrapersonal intelligence through a traditional game played by RKT A-level kindergarten students. This study aims to (1) improve interpersonal intelligence through traditional games, (2) increase intrapersonal intelligence through a traditional game, and (3) describe the process of improving interpersonal and intrapersonal intelligence through these traditional games.

\section{Method}

The approach used in this research is quantitative approach using Class Action Observation type (PTK). PTK model was coined by Kemmis and Taggart (2011). This model consists of four components on one cycle, namely (1) planning, (2) action, (3) observation, and (4) reflection. If the target has not been achieved after reflection, then a replanning will follow immediately to start the next cycle.

The research was conducted between September 2015 - April 2016 at RKT Kindergarten, Sleman, Yogyakarta. This kindergarten is located at Jl. Magelang KM 7 Mlati, Sleman, Yogyakarta, Indonesia.

As many as 17 A-level kindergarten students aged 4-5 years old at RKT kindergarten were recruited as subjects of this study.
Early-childhood children were chosen because they are more independent emotionally, expand skills for school preparation (i.e., motoric, cognitive, socio-emotional) and spends much time with their peers.

Treatment is given in the form of cycles. The number of cycles conducted in this research is yet to be determined because the applied cycle depends on whether the standard success score is obtained. This research consists of four procedures, namely planning, action, observation, and reflection.

Data collection are done through observation and interview. The observation data obtained through student and teacher activity during the learning process is analyzed using a qualitative descriptive method. The structured observation results in the form of interpersonal and intrapersonal intelligence was then analyzed quantitatively using descriptive statistics.

The four procedure steps are (1) Planning. This step arranges the action plan that we will do to fix and improve interpersonal and intrapersonal intelligence. (2) Action will be conducted in the form of a cycle. In this research, we were still unable to determine the number of cycles to be applied, because it depends on whether the success target could be achieved. Furthermore, the action is conducted on direct practice on the field. Thus, the plan of this action is temporary, flexible, and changeable according to the current condition to allow for improvement.

If one cycle has not met the standard of evaluation criteria, we will continue to the next cycle. (3) Observation. Observation is done by previously planning how and what tool will be used to collect data. We conducted the observation while the activity is currently running. It is done non-structurally during the game and learning process.

Additionally, a structured observation focusing on the students' improvement in interpersonal and intrapersonal intelligence is done after the activity is completed. The objective of observation and interview is to determine how much the students' interpersonal and intrapersonal intelligence have improved through traditional games. (4) Reflection aims 
to determine the limitations of the learning process and the evaluation by the collaborators of this research. Reflection is also a discussion between teacher and researcher that results in improvement plan for the next step. The reflection step is done by analyzing data, problems, and challenges found during the action step.

\section{Findings and Discussion}

Based on the improvement from each stage starting from pre-cycle, cycle I, and cycle II, interpersonal and intrapersonal intelligence are portrayed in Table 1 and Table 2. Based on table 1, children's interpersonal intelligence successfully increased from preaction (22.60) on the 'very low' category to 27.10 with 'low' category. Similarly, cycle 2 reached a score of 34.60 on the 'medium' level. Intrapersonal intelligence also increased from pre-action (16.80) on 'very low' category, cycle 1 (21.30) with 'low' category, and cycle 2 (25.90) with 'medium' category. Based on the analysis, the improvement is caused by the planning and action process. Good preparation of each cycle predicts a good result, even though each cycle conducted improvements to reach the determined standard.

The action that was done through Jamuran game includes introductory, core, and closing activity. Introductory activity introduces Jamuran and the lyrics to the game's song. During the core activity, teacher and researcher show Jamuran game to children by directly demonstrating the moves of this game. It also stimulates children's gross motor skills. On the closing activity, children are requested to describe their feelings while playing Jamuran. This helps stimulate children's language improvement.

Additionally, Jamuran also acts as a stimulus to improve intrapersonal intelligence on the dimension of identifying personal needs, like children knowing which mushroom (jamur in Jamuran means mushroom) they want. It is supported by Emolu (2014, p. 25) who stated that playing is one of the children's ways to socially interact with adults or peers. While playing, children can express their inner emotion freely. Traditional games can stimulate many of children's dimensions, especially on interpersonal and intrapersonal intelligence. Through those games, children can learn to socialize, maintain solidarity, control themselves or their emotion, and appreciate others (Seriati \& Hayati, 2010, p.115).

Through Jamuran, children's interpersonal and intrapersonal intelligence can be more easily stimulated. Traditional game, especially Jamuran, can ignite the interest of children to participate in the activity, mainly because the game involves movements and songs. Having both activities together will make students more enthusiastic to blend in with other children.

Table 1. Interpersonal intelligence on each stage of the cycle

\begin{tabular}{ccccc}
\hline Classification & Interval & Pre-cycle & Cycle 1 & Cycle 2 \\
\hline Very high & $\mathrm{x}>15.6$ & 0 & 0 & 0 \\
High & $13.2<\mathrm{x} \leq 15.6$ & 0 & 0 & 2 \\
Medium & $10.8 \leq \mathrm{x} \leq 13.2$ & 1 & 0 & 13 \\
Low & $8.4 \leq \mathrm{x} \leq 10.8$ & 8 & 17 & 2 \\
Very Low & $\mathrm{x}<8.4$ & 8 & 0 & 0 \\
\hline
\end{tabular}

Table 2. Intrapersonal intelligence on each stage of the cycle

\begin{tabular}{ccccc}
\hline Classification & Interval & Pre-Cycle & Cycle 1 & Cycle 2 \\
\hline Very high & $\mathrm{x}>15.6$ & 0 & 0 & 0 \\
High & $13.2<\mathrm{x} \leq 15.6$ & 0 & 0 & 0 \\
Medium & $10.8 \leq \mathrm{x} \leq 13.2$ & 0 & 10 & 17 \\
Low & $8.4 \leq \mathrm{x} \leq 10.8$ & 4 & 6 & 0 \\
Very Low & $\mathrm{x}<8.4$ & 13 & 1 & 0 \\
\hline
\end{tabular}


As previously mentioned, group traditional games require interaction with other people. Thus, interpersonal skill is developed during Jamuran when children sing and do a movement together. Children learn to work together so that the game will run smoothly. When children are looking for one kid that should be 'it', this is the time that is considered to develop children's interpersonal skill potentially. It is in line with Seriati and Hayati's opinion (2010, p. 112) who stated that playing in groups that involve movement and song could potentially develop children's social skill.

Finding also describes that children's intrapersonal intelligence is improved as an impact of the action. From the improvement, it shows that traditional game Jamuran can also be made as a stimulus to improve intrapersonal skill on the dimension of identifying personal needs, like when children know what mushroom that they want.

It is supported with Emolu (2014, p.25) who stated that playing is one of children's way of expressing their emotion freely. The traditional game can stimulate various dimensions of children development, especially on children's interpersonal and intrapersonal intelligence. Through the game, children can learn to socialize, maintain their solidarity, control themselves or their emotion, and learn to appreciate other people (Seriati \& Haryati, 201, p. 115).

Through movements and songs, children can be more motivated to follow the game. Moreover, there is also a presence of media that can make the game more interesting such as a hat, mask, and other additional media. It can make children more motivated and not feel bored with the game that is repeatedly played. Children's interest in the game will make it easier for both the teacher and researcher to stimulate improvement.

The repetition of the game that shows the improvement children's interpersonal and intrapersonal intelligence can affect the improvement of children's interpersonal and intrapersonal intelligence. It is in line with Thorndike's learning theory that says learning process is an interaction between stimulus and response. A repeated stimulus will strengthen a fixed respond from the children, causing behavior modification through learning (Slavin, 2000, p. 267).

Interpersonal and intrapersonal intelligence improvement is also easier to be stimulated because Jamuran sharpen their communication skill, social insight, social sensitivity, ability to identify personal need and express emotion. If those things can be expressed by children, then children's interpersonal and intrapersonal intelligence have been well-developed.

It is in line with Eberle's opinion (2011, p.23) who says that playing can stimulate mental and physical development as well as social skills. Development and playing on early childhood children has a deep relation so that it can help children in living their life. As an example, in their early stage of life, human learn to speak by playing until they can speak fluently by learning letters through games.

Other than being affected by media and method of Jamuran game, the success of the increasing skill of interpersonal and intrapersonal skill is also affected by teacher's skill in stimulating children to be able to show their interpersonal and intrapersonal skill. As stated by Wandansar (2014, p. 86), the role of (children's) environment is highly required in stimulating children's development. It can be seen in the form of social support such as instrumental support, reward from people around them, and emotional bond between teacher and children can help them to stimulate their development steps.

Interpersonal intelligence improvement on each dimension shows various scores on each cycle. The explanation of each dimension is as follows:

\section{Social Sensitivity}

There are a few indicators on social sensitivity dimension, namely skill of responding other people's behavior verbally and non-verbally (expression and body language). Based on researcher's observation, this dimension has an improvement from pre-cycle to cycle 2. Before action, children's interpersonal skill reached 8.18 on 'very low' category. It increased on cycle 1 to 10.35 on 'low' cate- 
gory and have improved again in cycle 2, reaching 13.05 on 'medium' category.

This is because, during pre-cycle, some children already showed their sensitivity towards surrounding environment. For example, there was a case when a teacher asked his or her student to tidy the room, one student immediately grab a broom and dustpan, while others flipped the carpet and swept the floor. Some other children play outside the classroom. After children were given action with traditional game, we observed the sensitivity towards surround environment on children that were previously only little of the children have the sensitivity, but then the number increased. For example, children can start to work together cleaning the classroom after playing. During the process, solidarity is also formed among them.

\section{Social Insight}

Social insight is about finding a solution for problems that emerged amidst children's social interaction. Mean score of social insight is low on both of the interpersonal dimensions, namely social communication and sensitivity. This is because only a few children that have social insight skill. Those are children who are brave enough to take action when a problem arises in the class. For example, two of the kids were fighting over a toy, another kid who witnessed the interaction immediately approached and told them to take turns in playing with the toy. If both children continued to fight until one of them cried, the witness it will report it to the teacher.

It is in line with what Yusuf (2010, p.31) opinion that stated that children's behavior development in adjusting themselves with the applied rules will develop in the society of where those children are in. Socialization behavior is something that is learned, not merely a result of individual's maturity, but also obtained from learning chance from response towards another person's behavior.

Children's proficiency in handling a problem (social insight) in a relation probably means that children have had an experience on the response that they do, so that they can do actions that are within social insight di- mension. However, some children that still not have good social insight, they probably have not had any experience of that response on their surrounding environment.

There are a few indicators on social insight dimension, those are, finding problem solving that is socially acceptable and skill of understanding any rules related to the interaction. Based on researcher's observation, this dimension has an increase from pre-cycle until cycle 2 . Before action, the mean score of children's interpersonal intelligence reached 6.47 on 'very low' category, increasing on cycle 1 into 7.7 in 'low' category and has an improvement on cycle 2 reaching 11.50 .

It is because the actions that were given on playing process help children to understand the existing rules in interacting with their friends and improve their problemsolving skill on their own environment. Each action requires children to follow the rule in the game. For example, children were asked to line up according to teacher's instruction, or when the teacher had given the instruction to line up, children ask each other to immediately make a line.

\section{Social Communication}

There are a few indicators in social communication dimension, those are, good listening skill and fluent speaking skill and understood by other people. Based on researcher's observation, this dimension has an improvement from pre-cycle until cycle 2 . Previously children's interpersonal intelligence reached 7.94 on 'very low' category. It increased on cycle 1 into 9.00 with 'low' category and has an improvement again on cycle 2 , reaching 11.90 on 'medium' category. It is because children are capable of listening and talk well and fluently, even though they do not have maximum comprehension yet.

According to Papalia and Feldman (2014, p.261), they stated that children aged 45 years old already have the knowledge to communicate, including knowing how to ask about something, how to tell a story, how to start and continue a conversation, and how to give commentary on the listener's perspective. Based on the description of the research result, children's intrapersonal intelligence in- 
creased from pre-action until cycle 2. It can be concluded that the improvement is caused by several changes during the action. The change was conducted by the researcher to anticipate children's boredom towards the actions, so that it makes children interested on the given action.

There are two dimensions of intrapersonal intelligence, namely to recognize emotions and self identity and knowing selfwants. Increased intrapersonal intelligence in each dimension shows the diversity of each cycle. The discussion on each dimension is as follows:

\section{Knowing emotions and self-identity}

There are several indicators in the dimension of knowing emotions and identity. Based on the observation of researcher, intrapersonal intelligence in children has increased from pre-cycle to cycle 2 . Before the action, children's intrapersonal intelligence reached 11.76 with 'very low' category. It increased in cycle 1 to 16.35 with 'low' category and increased again in cycle 2 reaching 19.82 with 'medium' category. It is because in every action taken during the activity, children show their feelings and the teacher stimulates the feelings of children with questions after the game is over.

According to Gardner and Power, children that have the ability to understand feelings, have the ability to control how children show their feelings to others and also be sensitive to other people's feeling. The ability to control their feeling help children to direct their behavior (in Papilia and Feldman, 2014, p. 275). After conducting observations and interviews, the results show that the dimensions of knowing emotions and self-identity always obtained higher score in each cycle than on the dimensions of knowing self-wants.

One of them is because children have not been able to know their own wants, children still need to be directed and guided by an adult to be able to know their selfwants. Like the theory that children aged 4-5 years old have the ability to understand and control feelings related to self-experience. When children have no experience on that particular situation, children can get confused of their self-wants (Papilia and Feldman, 2014, p.275).

\section{Identify Personal Needs}

There are several indicators in the dimension of identify personal needs. Findings showed that this dimension has an improvement from pre-cycle to cycle 2. Previously, the intrapersonal intelligence of the children reached 3.82 with 'very low' category, increased in cycle 1 to 5.00 with 'low' category and increasing again in cycle 2 reaching 6.06 with 'medium' category. This is because children show the ability to know what they want.

Children have the ability to understand the feelings of others. Children understand that feelings are strongly related to experiences and wants (Libble \& Thompson, 1998) and contributes to children's ability to make friendship (in Papilia \& Feldman, 2014, p. 275). In addition, children know more about each other's identity. This is because in the process of learning in RKT coincides with the theme of 'myself' that is being studied by the children, so children can easily show the desired behavior by researcher.

As for the dimensions of identifying personal need, children still seem to need to be given direction and guidance to find the wants of each child. To be able to know their self-want, children must be given more stimulus to be able to answer the questions from researcher. However, children of 5-6 years old are considered to be able to develop their intrapersonal intelligence.

This is in line with statements from Jamaris and Edwita (2014) stating that children aged 4-6 years' intrapersonal skill develops as they learn to know more about themselves. Santrock (2007, p.378) says that intrapersonal intelligence is related to knowing about themselves which is shown by selfconcept which includes recognizing self identity and knowing difference of themselves with others.

\section{Conclusion and Suggestions}

Conclusion

Implementation of activities through traditional games can stimulate the develop- 
ment of interpersonal and intrapersonal intelligence for children, affecting the level of achievement in accordance with predetermined standards. Through traditional game activities, the interpersonal developed in Jamuran is formed as children sing and move together. They learn to work together in running the game smoothly. Children look active and interactive with teachers and peers (interpersonal). As in children's play is shown to express self-emotion and children can express the feeling of self at the end of the game (intrapersonal), this makes the traditional game can be one of the media and methods to increase intrapersonal intelligence.

The interpersonal intelligence of the RKT kindergarten children A can be improved using the traditional game of mushrooms. This is evident through the overall improvement of interpersonal intelligence on the cycles. At first, the mean score of interpersonal intelligence was 22.60 on 'very low' category, increasing to 27.10 in cycle 1 (low category) and increase again in cycle 2 with 34.70 on 'medium' category.

The intrapersonal intelligence of RKT A-level kindergarten students can be improved by Jamuran traditional game. This can be seen in the improvement of overall intrapersonal intelligence from pre-cycle with an average score of 16.80 with very low category increased in cycle 1 to 21.40 with low category and increasing again in cycle 2 to 25.90 with medium categorycan be in the form of finding generalization according to the research problems, or recommendations for further steps. Meanwhile, suggestions can be in the form of input/proposition for future researchers, or implicative recommendations from the research findings.

\section{Suggestions}

The school should keep trying to improve the development of interpersonal and intrapersonal intelligence of their students and create learning conditions that pay attention to the facilities and infrastructure to support the development of their interpersonal and intrapersonal intelligence.

Classroom teachers should be more creative in creating a classroom with a conducive atmosphere and create a medium to stimulate interpersonal and intrapersonal development of children by creating a fun condition, preventing students from feeling bored with the learning activities.

\section{References}

Brewer, J.A. (2007). Introduction to early education: Preschool through primary grades. United States: Pearson.

Denevers, D.M. (2014). Interpersonal intelligence and problem-based learning. Master of education program theses. Paper 53.

Emolu, E. (2014). Play, toy and gender socialization. Journal Plus Education, 11(2), 22-30.

Eberle, S. (2011). Playing with the multiple intelligences how plays helps them grow. American Journal, 4(1), 19-51.

Gardner, H. (2006). Multiple intelligences: The theory in practice (5th ed.). New York, NY: Basic Books.

Gardner, H. (2013). Multiple intelligences (kecerdasan majemuk). Batan: Interaksara.

Jamaris, M. \& Edwita. (2014). Formal multiple intelligences assesment instrument for 4-6 years old children. American Journal of Education Research, 2(12), 1167-1174.

Lwin, M. (2008). Cara mengembangkan berbagai komponen kecerdasan. Yogyakarta: PT. Indeks.

Papalia, D.E. \& Feldman, R.D. (2014). Menyelami perkembangan manusia (12th ed.). Jakarta: Salemba Humanika.

Saad, H.M. (2006). Perkelabian pelajar: Potret siswa SMU di DKI Jakarta. Yogyakarta: Galang Press.

Santrock, J.W. (2007). Life span development $\left(5^{\text {th }}\right.$ ed.). Jakarta: Erlangga.

Seriati, N.N. \& Hayati, N. (2010). Permainan tradisional jawa gerak dan lagu untuk menstimulasi keterampilan sosial anak usia dini. Accessed on 22 June 2016 from http://staff.uny.ac.id/sites/default/files 
/Artikel\%20Permainan\%20Tradisonal. pdf.

Slavin, R.E. (2011). Educational psychology: Theory and practice (10th ed.). Boston, MA: Pearson.

Smith, M.K. (2008). Howard Gardner, multiple intelligences and education. Accessed on 16 September 2014 from http://Infed.Org/Mobi/HowardGardner-Multipleintelligences-AndEducation/.

Sujiono, Y.N. (2013). Konsep dasar pendidikan anak usia dini. Jakarta: Indeks.
Sungur, S. \& Tekkaya, C. (2006). Effects of problem-based learning and traditional instruction on self-regulated learning. Journal of Educational Research, 99(5), 307317.

Wandansari, F. (2014). Perkembangan anak dalam lingkungan. Bandung: Rosdakarya.

Yusuf, S. (2010). Psikologi perkembangan anak dan remaja. Bandung: Rosdakarya. 